\title{
BENTUK BAHASA PENOLAKAN MASYARAKAT MUSLIM TERHADAP TAWARAN MAKAN DARI MASYARAKAT NASRANI DI KOTA KUPANG
}

\section{FORMS OF REJECTION LANGUAGE OF MUSLIM SOCIETY TOWARD MEAL OFFER FROM CRISTIAN SOCIETY IN KUPANG CITY}

\author{
${ }^{1}$ Abdul Rahim Arman P. Dapubeang, ${ }^{2}$ Kristofel Bere Nahak \\ Universitas Timor \\ 1ㅅrmandapubeang32@gmail.com, ${ }^{2}$ berekristofel@unimor.ac.id
}

\begin{abstract}
Abstrak
Adanya kekhawatiran terhadap peralatan makan yang terkena najis baik dari daging babi atau anjing maupun dari bekas jilatan anjing menjadi salah satu alasan kaum muslim menolak tawaran makan dari kaum nasrani di kota Kupang. Penelitian ini memiliki masalah bagaimanakah bentuk bahasa penolakan kaum muslim atas tawaran makan dari kaum nasrasi di rumahnya. Penelitian ini merupakan penelitian kualitatif. Teknik pengumpulan data yang digunakan dalam penelitian ini adalah teknik simak bebas libat cakap, teknik rekam, dan teknik catat. Sedangkan teknik analisis data dalam penelitian ini menggunakan analisis heuristik. Analisis heuristik merupakan proses berpikir seseorang untuk memaknai suatu tuturan. Tuturan heuristik diinterprestasikan berdasarkan berbagai kemungkinan/dugaan sementara, kemudian dugaan sementara itu disesuaikan dengan fakta-fakta pendukung yang ada di lapangan. Berdasarkan hasil penelitian, ditemukan dua bentuk penolakan dari kaum muslim terhadap tawaran makan dari kaum nasrani di Kota Kupang, yaitu penolakan langsung dan penolakan tidak langsung. Penolakan langsung terdiri dari dua jenis penolakan yaitu penolakan performatif dan konstantif. Sedangkan penolakan tidak langsung terdiri dari tujuh jenis penolakan, yaitu: 1) penolakan dengan alasan, 2) penolakan dengan alternatif, 3) penolakan dengan berjanji, 4) penolakan dengan penyesalan, 5) penolakan dengan penerimaan di masa depan, 6) penolakan dengan prinsip, dan 7) penolakan dengan penghindaran.
\end{abstract}

Kata Kunci: penolakan, tawaran makan, muslim, nasrani

\begin{abstract}
There are concerns about cutlery affected by eitherpork or dog or the former dog's saliva to be one of the reasons Muslims refuse the offer of food from the Christians in the city of Kupang. This research aims to identify the language of rejection of Muslims for the offer of eating of the christins in their home. This research is a qualitative study. The data collection techniques used in this research are proficient free watch techniques, recording techniques, and note techniques. While the data analysis techniques in this research use the heuristic analysis. Heuristic analysis is a process of people mindset to interpret a speech. The heuristic Tuturan is intercoordinated based on a variety of potential/suspected temporary, then suspected while it is adapted to the supporting facts that exist in the society. Based on the results of this research, identified two forms of rejection from Muslims about food offerings from the christians in Kupang are direct rejection and indirect rejection. Direct rejection consists of two types of rejection, namely performative and constant rejection. Meanwbile, indirect rejection consists of seven types of rejections, namely: 1) rejection by reason, 2) rejection by alternative, 3) rejection by pledge, 4) rejection with regret, 5) rejection with future acceptance, 6) rejection Principles, and 7) rejection by avoidance.
\end{abstract}

Key Words: Refuse, Food offering, Muslim, Christian.

\section{PENDAHULUAN}

Salah satu hakikat bahasa menurut Kridalaksana (1983) adalah bahasa bersifat manusiawi. Artinya, hanya manusialah yang memiliki dan menggunakan bahasa. Hakikat ini menjelaskan bahwa antara manusia dan bahasa memang tidak bisa dipisahkan satu sama lain. 


\section{Abdul Rahim Arman P. Dapubeang dan Kristofel Bere Nahak Universitas Timor}

Hanya melalui bahasalah manusia dapat saling berkomunikasi dalam menyampaikan pikiran, perasaan, dan pengalaman kepada mitra tuturnya.

Penyampaian berbagai bentuk informasi tersebut harus dilakukan dengan jelas dan efektif. Apa yang disampaikan oleh penutur dapat dipahami sama baiknya oleh mitra tutur. Jika proses komunikasi tidak terjadi secara baik, maka dapat terjadi kesalahapahaman dalam mencerna informasi antara penutur dan mitra tutur. Oleh sebab itu, dalam proses komunikasi perlu dilibatkan pula unsur-unsur di luar linguistik seperti unsur sosiologi, psikologi, konteks, dan lain sebagainya.

Segala bentuk informasi yang disampaikan oleh penutur tentu ada yang membutuhkan tanggapan balik dari mitra tutur. Tanggapan balik tersebut dapat berupa persetujuan atau penolakan. Persetujuan adalah menyatakan dengan verbal atau nonverbal untuk menerima suatu ajakan, tawaran, atau permintaan. Sedangkan penolakkan adalah menyatakan dengan verbal atau nonverbal untuk tidak menerima suatu ajakan, tawaran, atau permintaan (Kartomiharjo, 1990: 14).

Adanya penolakan dalam suatu peristiwa komunikasi dapat disebabkan oleh faktor tertentu. Faktor tersebut dapat berkaitan dengan pertentangan dalam diri mitra tutur, baik dari segi idiologi maupun keyakinan dan lain sebagainya. salah satu peristiwa penolakan yang paling sering terjadi dalam proses komunikasi adalah penolakan kaum muslim terhadap tawaran makan dari kaum nasrani di rumahnya. Salah satu alasan penolakan tersebut terjadi atas dasar keyakinan keagamaan. Bagi kaum muslim, terdapat banyak aturan tentang makanan dan minuman yang boleh (halal) dikonsumsi dan tidak boleh (haram) dikonsumsi. Bahkan ada makanan yang pada dasarnya berstatus halal, namun karena faktor tertentu makanan tersebut berganti sifat menjadi haram untuk dikonsumsi. Contohnya adalah hewan yang dihalalkan (kambing, sapi, ayam, bebek, dan lain sebagainya) namun disembelih tidak dengan menyebut nama Allah SWT, maka statusnya berubah menjadi haram. Contoh lainnya adalah makanan yang dimasak dengan menggunakan wadah yang terkena najis dari liur anjing. Walaupun makanan tersebut awalnya halal, namun jika terkontaminasi wadah yang bernajis maka statusnya berubah menjadi haram. Kehati-hatian kaum muslim dalam mengonsumsi makanan ini dilandaskan pada konsekuensi yang harus diterima, yaitu ditolaknya amal ibadah dalam kurun waktu tertentu sebagaimana yang terdapat dalam literatur ajaran Islam yaitu AlQuran dan Hadits Nabi Muhammad saw.

Ajaran tentang makan dan minuman yang diyakini oleh kaum muslim ini berbeda dengan pola makan kebanyakan kaum nasrani khususnya di kota Kupang. Banyak dari kaum nasrani di kota Kupang yang mengonsumsi daging anjing dan daging babi yang diharamkan untuk kaum muslim. Selain itu, banyak dari kaum nasrani yang memelihara anjing di rumahnya. Sehingga tidak menutup kemungkinan peralatan makan dan minum di rumah kaum nasrani terkena liur anjing peliharaannya.

Kondisi inilah yang membuat kaum muslim merasa kuatir jika ditawari makan oleh kaum nasrani di rumahnya. Karena untuk menyucikan kembali peralatan makan yang telah terkontaminasi najis tidak cukup hanya dengan mencucinya sebagaimana yang sering dilakukan sehari-hari. Tetapi harus didasarkan pada ajaran syar'i sesuai hadits Nabi Muhammad saw, "cara mensucikan bejana dari seseorang di antara kalian jika dijilat anjing 
adalah dengan mencucinya tujuh kali, cucian yang pertama menggunakan tanah" (HR. Al Bukhari No. 182, Muslim No. 279).

Walau penolakan kaum muslim terhadap tawaran makan dan minum dari kaum nasrani ini dilandasi oleh dasar keyakinan agama, namun mayoritas kaum nasrani belum mengetahuinya. Ketidaktahuan ini dikarenakan kurangnya diskusi lintas agama khususnya yang membahas tentang makanan dan minuman. Akibatnya, banyak kaum nasrani yang beranggapan bahwa penolakan tersebut karena faktor lain seperti makanan yang disajikan tidak enak dan lain sebagainya. Sehingga seringkali terjadi kesalahpahaman namun tidak pernah berujung konflik.

Peristiwa penolakan kaum muslim terhadap tawaran makan dari kaum nasrani ini banyak terjadi di Kota Kupang. Hal ini karena tingkat interaksi pergaulan sosial lintas agama yang sangat baik. Sehingga kegiatan saling kunjung-mengunjungi antar warga yang berbeda agama bukan merupakan hal yang tabu. Walaupun terdapat beberapa hal berkaitan dengan agama yang membatasi pergaulan, namun hal tersebut bukan penghalang untuk membangun keakraban. Hal ini terbukti dari penghargaan yang diperoleh kota Kupang, sebagai kota ke 7 dengan tingkat toleransi tertinggi di Indonesia pada tahun 2018.

Fenomena penolakan ajakan makan oleh kaum muslim atas tawaran dari kaum nasrani di rumahnya ini merupakan suatu bentuk tindak tutur. Hal ini perlu dikaji lebih dalam karena terdapat banyak bentuk bahasa penolakan. Bentuk-bentuk bahasa penolakan tersebut didasarkan pada situasi, kondisi, pertimbangan kesopanan, pertimbangan kekerabatan, dan lain sebagainya. Maka dari itu, dipandang perlu untuk dilakukan penelitian dengan judul "Bentuk Bahasa Penolakan Kaum Muslim terhadap Tawaran Makan dari Kaum Nasrani di Kota Kupang."

Penelitian yang membahas tentang bahasa penolakan telah banyak dilakukan. Penelitian terdahulu yang terkait dengan penelitian ini adalah penelitian yang dilakukan oleh Tri Budi Utami (2006) yang berjudul "Analisis Pragmatik Bahasa Penolakan dalam Wacana Chatting di Internet Netrone". Adapun hasil penelitian ini adalah: (1) bentuk bahasa penolakan yaitu penolakakn dengan menggunakan kata nggak dan gak, penolakakn dengan mengnakan alsan, pertanyaan, dan ucapan terima kasih, (2) asumsi-asumsi pragmatik yang terdapat dalam bahasa penolakan adalah tindak tutur langsung, tindak tutur tak langsung, tindak tutur literal, dan tindak tutur tak literal, (3) pelaksanaan prinsip kerja sama yang terdapat dalam bahasa penolakakn adalah maksim kualitas, maksim kuantitas, maksim relevansi, dan maksim pelaksanaan. Adapun maksim pelaksanaan yang terdapat dalam prinsip kesopanan adalah maksim kebijaksanaan dan maksim kemurahan.

Selain itu, penelitian tentang bahasa penolakan juga dilakukan oleh Bayu Kusuma Mada (2013) mahasiswa sastra Jepang Universitas Dian Nuswantoro dengan judul "Analisis Ungkapan Penolakan Bahasa Jepang dalam Film Ranma 1/2". Penelitian ini meneliti tentang ragam bahasa, struktur, strategi yang digunakan saat melakukan penolakan. Hasil dari penilitian ini adalah ragam bahasa hormat digunakan oleh orang yang kedudukannya lebih tinggi, orang luar, dan pada situasi yang formal. Strategi pada penolakan digunakan untuk memperlunak penolakan, selain itu juga digunakan untuk menjaga hubungan antar sesama individu. 


\section{Abdul Rahim Arman P. Dapubeang dan Kristofel Bere Nahak Universitas Timor}

Persamaan dari penelitian yang dilakukan oleh Tri Budi Utami dan Bayu Kusuma Mada dengan penelitian ini adalah sama-sama mengkaji tentang bentuk bahasa bahasa penolakan. Adapun perbedaannya adalah penelitian yang dilakukan Tri Budi Utami lebih menekankan pada sisi pragmatik bentuk bahasa penolakan dan penelitian yang dilakukan oleh Bayu Kusuma Mada lebih terfokus pada tindak tutur penolakan beserta strategi yang digunakan. Sedangkan penelitian ini lebih cenderung pada analisis sosiolinguistik bentuk bahasa penolakan yang digunakan dalam menolak tawaran makan.

\section{METODE PENELITIAN}

Data dalam penelitian ini meliputi tindak tutur menolak oleh kaum muslim terhadap tawaran makan dari kaum nasrani di rumahnya. Sedangkan sumber data dalam penelitian ini adalah catatan dan rekaman percakapan lisan yang di dalamnya terdapat tindak tutur menolak yang dituturkan oleh narasumber. Data dalam penelitian ini menggunakan teknik simak bebas libat cakap dan teknik rekam. Sehingga peneliti tidak terlibat langsung dalam percakapan. Peneliti hanya memperhatikan dan mendengarkan tuturan-tuturan dalam suatu peristiwa tutur sambil merekamnya. Kemudian rekaman tersebut ditranskripkan dan dianalisis. Adapun teknik analisis data yang digunakan adalah teknik heuristik. Teknik heuristik berusaha mengidentifikasi daya pragmatik suatu tuturan dengan merumuskan hipotesishipotesis dan kemungkinan mengujinya dengan data-data yang tersedia (Leech, 1993: 61).

\section{HASIL DAN PEMBAHASAN}

\section{Hasil Penelitian}

Berdasarkan hasil penelitian yang dilakukan, ditemukan sembilan kategori bahasa penolakan. Sembilan kategori tersebut dapat diklasifikan ke dalam dua jenis tindak tutur penolakan, yaitu tindak tutur penolakan langsung dan tindak tutur penolakan tidak langsung. Tindak tutur penolakan langsung terdiri dari dua kategori bahasa penolakan yaitu performatif dan konstantif. Sedangkan tindak tutur penolakan tidak langsung terdiri dari tujuh kategori bahasa penolakan yaitu penolakan dengan alasan, penolakan dengan alternatif, penolakan dengan berjanji, penolakan dengan penyesalan, penolakan dengan penerimaan di masa depan, penolakan dengan prinsip, dan penolakan dengan penghindaran.

\section{a. Penolakan Performatif}

Tindak Tutur menolak langsung dengan kalimat performatif merupakan strategi tindak tutur menolak dengan menggunakan verba yang menunjukkan tindakan penolakan, yaitu dengan verba menolak (Beebe at all dalam Yamagashira, 2001: 274). Adapun data yang menunjukan bahasa penolakan dengan menggunakan kalimat perfomatif sebagai berikut:

$\begin{array}{cc}\text { Nasrani } & \text { : Zal mari makan dolo } \\ & \text { (Zal mari makan dulu) } \\ \text { Muslimin } & : \text { Sudah, sonde usah } \\ & \text { (Sudah, tidak usah) } \\ \text { Nasrani } & : \text { Ko makan dolo } \\ & \text { (Mari makan dulu) }\end{array}$


Muslimin : Sudah, sonde usah repot-repot

(Sudah, tidak usah repot-repot)

Kutipan di atas menunjukkan bahwa penutur muslim tidak ingin makan di rumah mitra tuturnya dengan menolak secara langsung yang ditandai dengan penggunaan kata "tidak" (sonde). Selain menggunakan kata "tidak" (sonde), penutur muslim juga menggunakan kata "sudah" di awal kalimat. Penggunaan kata "sudah" di awal kalimat jika dikaitkan dengan konteks penawaran dalam Dialek Melayu Kupang (DMK) bersepadan dengan kata "tidak". Sehingga terdapat pendobelan penggunaan kata tidak yang menunjukan penolakan dengan tegas. Walau menolak, namun penutur muslim tidak meninggalkan rumah penutur nasrani.

\section{b. Penolakan Konstantif}

Tindak tutur menolak langsung dengan kalimat konstantif merupakan strategi tindak tutur menolak dengan menggunakan kata tidak dengan mengungkapkan ketidaksanggupan untuk memenuhi keinginan mitra tutur (Beebe at all dalam Yamagashira, 2001: 274). Adapun data yang menunjukan bahasa penolakan dengan menggunakan kalimat konstantif sebagai berikut:

Nasrani : Mari su katong pi belakang dolo

(Mari, kita ke belang dulu)

Muslimin : Buat?

(Untuk apa?)

Nasrani : Maitua ada siap nib

(Istri sudah menyiapkan makan)

Muslimin : Be sonde makan lae masi kinyang ni

(Saya tidak makan lagi, masih kenyang)

Nasrani : Ko mari sudah

(Ayo mari makan)

Muslimin : Biar su perut su sonde muat le ni

(Tidak usah, perut sudah tidak muat lagi)

Nasrani : jang begitu, mari sudah eh

(jangan begitu, ayo mari makan)

Muslim : Betul kawan e, ini kalo be paksa makan be muntah, talalu

kinyang na

(Serius tema, kalau saya paksa untuk makan, saya akan muntah karena terlalu kenyang)

Kutipan di atas menunjukan bahwa penutur muslim menolak tawaran makan secara langsung dari mitra tuturnya dengan menunjukan ketidakmampuannya. Penolakan secara langsung ditandai dengan kata "tidak" (sonde) sedangkan ketidakmampuan ditandai dengan ungkapan "masih kenyang" (masi kinyang). Ungkapan masih kenyang menunjukan bahwa penutur muslim tidak mampu untuk makan lagi karena telah makan sebelum bertamu ke rumah mitra tuturnya. Penutur muslim juga memperkuat alasan ketidakmampuanya untuk menerima tawaran makan di ucapan selanjutnya, yaitu perut sudah tidak mampu menampung makanan lagi (perut su sonde muat lagi). Bahkan ketidakmampuan penutur muslim semakin 


\section{Abdul Rahim Arman P. Dapubeang dan Kristofel Bere Nahak Universitas Timor}

dipertegas apabila ia makan, maka ia akan muntah (kalo be paksa makan be muntah) karena merasa sangat kenyang (talalu kinyang na).

\section{c. Penolakan dengan Alasan}

Penolakan dengan alasan digunakan penutur untuk menjelaskan alasan atau penyebab spesifik mengapa tidak bisa memenuhi keinginan mitra tutur (Beebe at all dalam Yamagahsira, 2001: 274). Adapun data yang menunjukan bahasa penolakan dengan menggunakan alasan sebagai berikut:

$\begin{array}{cl}\text { Nasrani } & \begin{array}{l}\text { : Kawan mari katong makan dolo } \\ \text { (Kawan mari kita makan dulu) }\end{array} \\ \text { Muslimin } & \begin{array}{l}\text { : Lanjut tadi beta baru makan sa } \\ \text { (Terimakasih tadi saya baru saja makan) }\end{array} \\ \text { Nasrani } \quad \text { Ko lu pung parah le } \\ \text { (Jangan begitu) }\end{array}$

Kutipan di atas menunjukan bahwa penutur muslim menolak tawaran makan dari mitra tuturnya dengan mengajukan suatu alasan. Alasan yang digunakan untuk menolak tawaran makan dari mitra tuturnya adalah "baru saja makan" (Lanjut, tadi beta baru makan na). Alasan "baru saja makan" (Lanjut tadi beta baru makan na) merupakan bentuk ilokusi yang disampaikan dengan harapan mitra tutur tidak menawarkan makan lagi. Sebab penutur muslim telah makan dan masih merasa kenyang.

\section{d. Penolakan dengan Alternatif}

Penolakan dengan alternatif digunakan penutur untuk menawarkan alternatif lain sebagai pengganti keinginan atau tawaran yang telah ditolak (Beebe at all dalam Yamagahsira, 2001: 274). Adapun data yang menunjukan bahasa penolakan dengan menawarkan alternatif sebagai berikut:

\begin{tabular}{|c|c|}
\hline Nasrani & $\begin{array}{l}\text { : Mari sudah ada yang enak ni } \\
\text { (Ayo, ada yang enak nih) }\end{array}$ \\
\hline Muslimin & $\begin{array}{l}\text { : Enak apa? } \\
\text { (Apanya yang enak?) }\end{array}$ \\
\hline Nasrani & $\begin{array}{l}\text { : Maitua ada masak ayam,mari su } \\
\text { (Istri ada masak daging ayam, mari silahkan) }\end{array}$ \\
\hline Muslimin & $\begin{array}{r}\text { Sudab lanjut sa, beta lebih suka ikan na } \\
\text { (Terima kasih, saya lebih suka ikan) }\end{array}$ \\
\hline Nasrani & $\begin{array}{c}\text { : Ko pake begitu lae } \\
\text { (Kok begitu) }\end{array}$ \\
\hline
\end{tabular}


Muslimin : Betul ni, lanjut su

(Serius, silahkan dilanjutkan)

Kutipan di atas menunjukan bahwa penutur muslim menolak tawaran makan dari mitra tuturnya dengan berdalih tidak menyukai atau kurang menyukai menu yang ditawarkan, sehingga penutur muslim mengajukan alternatif sesuai dengan yang ia sukai. Kondisi yang terjadi pada saat peristiwa tutur ini berlangsung adalah penutur nasrani menawarkan makan kepada penutur muslim dengan menu utama daging ayam goreng (Maitua ada masak ayam, mari su). Namun penutur muslim merasa tidak nyaman karena tidak mengetahui proses penyembelihan dan pengolahan daging ayam tersebut, apakah sesuai dengan syariat/hukum Islam atau tidak. Sebab dalam ajaran Islam proses penyembelihan sangat mempengaruhi status daging (ayam goreng) yang disajikan tersebut halal atau haram. Oleh karena itu, penutur muslim melakukan penolakan dengan mengajukan alternatif lebih suka makan dengan lauk ikan daripada daging ayam (Sudah lanjut su, beta lebih suka ikan na). Hal ini karena dalam ajaran Islam semua ikan bahkan bangkai ikan sekalipun halal untuk dikonsumsi sebagaimana yang dijelaskan Nabi Muhammadi saw dalam haditsnya.

\section{e. Penolakan dengan Berjanji}

Penolakan dengan berjanji digunakan dengan maksud memberikan pernyataan atau janji bahwa akan menyanggupi keinginan mitra tutur di lain waktu yang akan datang (Beebe at all dalam Yamagahsira, 2001: 274). Adapun data yang menunjukan bahasa penolakan dengan menggunakan janji sebagai berikut:

\begin{tabular}{|c|c|}
\hline Nasrani & $\begin{array}{l}\text { : Mari su katong pi belakang su } \\
\text { (Ayo, mari kita ke belakang) }\end{array}$ \\
\hline Muslimin & : (Berdiri mengenakan jaket) \\
\hline Nasrani & $\begin{array}{l}\text { : He? Mo pi mana? } \\
\text { (Loh, mau kemana?) }\end{array}$ \\
\hline Muslimin & $\begin{array}{l}\text { : Bos ada w.a beta surub pi kantor sekrang ni } \\
\text { (Bos mengirimi saya pesan untuk segera menghadap di kantor) }\end{array}$ \\
\hline Nasrani & $\begin{array}{l}\text { : He ko pung parah le, lu sifat jelek mati lu ni } \\
\text { (Kok begitu? Sifat mu sangat buruk) }\end{array}$ \\
\hline Muslimin & $\begin{array}{l}\text { : Lanjut su be ada buru-buru ni, nanti kapan-kapan baru be } \\
\text { singgah ko makan } \\
\text { (Terima kasih, saya sedang terburu-buru, nanti kapan-kapan } \\
\text { baru saya singgah untuk makan) }\end{array}$ \\
\hline Narani & $\begin{array}{l}: \text { Betulo } \\
\text { (benar?) }\end{array}$ \\
\hline Muslimin & : Betul eb \\
\hline
\end{tabular}

(Ia benar)

Kutipan di atas menunjukan bahwa penutur muslim menolak tawaran makan dari mitra tuturnya dengan menunjukan sikap terburu-buru untuk pergi. Sikap tersebut ditunjukan karena penutur muslim mendapatkan pesan melalui aplikasi whatsup (w.a) dari atasannya untuk segera menghadap (Bos ada w.a beta suruh pi kantor sekrang ni). Padahal 


\section{Abdul Rahim Arman P. Dapubeang dan Kristofel Bere Nahak Universitas Timor}

sebelumnya tidak terlihat tandap-tanda baik berupa suara, cahaya, maupun getaran dari telepon genggam penutur muslim yang menandakan adanya pesan yang masuk. Sehingga untuk tidak mengecewakan mitra tuturnya yang menawarkan makan, penutur muslim berjanji akan kembali untuk menerima tawaran makan dari mitra tutur walau tanpa kepastian waktu kapan ia akan kembali (Lanjut su be ada buru-buru ni, nanti kapan-kapan baru be singgab ko makan). Janji tersebut dikonfirmasi ulang oleh penutur nasrani (betul o) dan dipertegas oleh penutur muslim (betul eb).

\section{f. Penolakan dengan Penyesalan}

Menolak dengan penyesalan digunakan dengan maksud untuk mengungkapkan penyesalan karena tidak dapat menyanggupi keinginan mitra tutur (Beebe at all dalam Yamagahsira, 2001: 274). Adapun data yang menunjukan bahasa penolakan dengan menggunakan ungkapan penyesalan sebagai berikut:

\begin{tabular}{|c|c|}
\hline Nasrani & $\begin{array}{l}\text { Ka mari makan dolo ko? } \\
(\text { Ka mari makan dulu) }\end{array}$ \\
\hline Muslimin & $\begin{array}{l}\text { : Adu jang marah bo'i, tadi baru makan di kantor ni } \\
\text { (Jangan marah sayang (sapaan), tadi saya baru makan di } \\
\text { kantor) }\end{array}$ \\
\hline Nasrani & $\begin{aligned} \text { : Na ka makan le to, beta su masak ni } \\
\text { (Kalau begitu makan lagi, saya sudah masak) }\end{aligned}$ \\
\hline Muslimin & $\begin{array}{l}\text { : Sudah bo'i, lain kali sa } \\
\text { (Sudah sayang (sapaan) lain kali saja) }\end{array}$ \\
\hline
\end{tabular}

Kutipan di atas menunjukan bahwa penutur muslim menolak tawaran makan dari mitra tuturnya dengan menunjukan rasa penyesalan. Rasa penyesalan diwujudkan dengan dua ungkapan, yaitu permintaan maaf dalam bentuk ungkapan "jangan marah" dan penggunaan honorifik "bo'?" (Adu jang marah bo'i). Pengunaan ungkapan “jangan marah” (jang marah) merupakan bentuk permintaan maaf yang lazim digunakan oleh masyarakat Kota Kupang untuk meredam perasaan negatif seperti tersingung, jengkel, dan sebagainya dari mitra tuturnya. Sedangkan Penggunaan honorifik " $b o$ ' $\imath$ ” digunakan sebagai bentuk rayuan agar permintaan maafnya dapat diterima. Honorifik " $b o$ ' " adalah bentuk penyapaan masyrakat Rote yang berarti “sayang”. Makna "sayang” yang dimaksud dalam sosial budaya masyarakat Rote adalah sayang secara umum, bukan sayang secara khusus seperti dalam konteks romansa.

\section{g. Penolakan dengan Penerimaan di Masa Depan}

Menolak dengan penerimaan di masa depan digunakan dengan maksud akan menerima keinginan mitra tutur di masa depan (Beebe at all dalam Yamagahsira, 2001: 274). Adapun data yang menunjukan bahasa penolakan dengan memberikan harapan akan diterima di masa yang akan datang sebagai berikut:
Nasrani
: Teman mari su maitua su panggil tu
(Teman, ayo, istri sudah pangil)
Muslimin : Haits sudah su be mo jalan ni 
(Haits, sudah saya mau jalan)

Nasrani : Ko mo makan baru jalan karmana

(Kenapa mau makan baru jalan)

Muslimin : Ho sudah, lain kali sa

(Iya sudah, lain kali saja)

Kutipan di atas menunjukan bahwa penutur muslim menolak tawaran makan dari mitra tuturnya dengan menyatakan akan segera pergi (haits, be su mau jalan ni) tanpa menjelaskan alasan kenapa harus segera pergi di saat makanan sudah disiapkan. Agar tidak membuat mitra tuturnya tersingung dengan sikapnya, maka penutur muslim pun menyatakan akan menerima tawaran makan tersebut di masa yang akan datang (bo sudab lain kali sa).

\section{h. Penolakan dengan Prinsip}

Menolak dengan prinsip digunakan dengan maksud mengutarakan pedoman yang diyakini penutur untuk menolak keinginan mitra tutur (Beebe at all dalam Yamagahsira, 2001: 274). Adapun data yang menunjukan bahasa penolakan dengan prinsip sebagai berikut:

Nasrani : : Man mari katong su, lapar nih

(Man mari kita makan dulu, sudah lapar soalnya)

Muslimin : Eh ko basong kemarin ada makan $\mathrm{RW}$ tu

(Tidak mau, karena kemarin kalian makan daging RW)

Nasrani : Ko piring dong su cuci a

(Piringnya sudah kami cuci)

Muslimin : Beta sonde bisa, itu be harus cuci pake tanah dolo

(Tidak bisa, saya harus mencucinya dengan tanah dulu)

Nasrani : Begitulai ko?

(Begitu kah)

Muslimin $\quad$ : Ko Tuhan pung mau begitu na karmana su, besong makan su be di sini sa

(Ia, sebab itu perintah dari Tuhan, kalian makan saja, biar

saja menunggu di sini)

Kutipan di atas menunjukan bahwa penutur muslim menolak tawaran dari mitra tuturnya atas dasar keyakinannya sebagai muslim. Penutur muslim mengetahui bahwa di hari sebelumnya, mitra tuturnya mengonsumsi daging RW (eh ko basong kemarin ada makan RW $t u$ ). Daging RW merupakan sebutan untuk daging anjing di Kota Kupang. Sehinga ada kekhawaitran dalam benak penutur muslim kalau peralatan makan yang digunakan telah terkontaminasi dengan najis. Sehingga untuk menggunakan peralatan tersebut tidak cukup dicuci seperti biasa, tetapi harus menggunakan tanah sebagai mana tuntunan Nabi Muhammad saw dalam haditsnya (Beta sonde bisa, itu be harus cuci pake tanah dolo).

\section{i. Penolakan dengan Penghindaran}

Penutur merespon keinginan mitra tutur dengan menghindar secara nonverbal (misalnya diam, ragu-ragu, tidak melakukan apa-apa, atau meninggalkan secara fisik), atau secara verbal (misalnya mengganti topik, bercanda, mengulangi bagian dari permintaan. 


\section{Abdul Rahim Arman P. Dapubeang dan Kristofel Bere Nahak Universitas Timor}

Contoh "Senin?" (menunda), "Saya pikir-pikir dulu" atau "Saya tidak tahu" (menghindar) (Beebe at all dalam Yamagahsira, 2001: 274). Adapun data yang menunjukan bahasa penolakan dengan penghindaran sebagai berikut:

\begin{tabular}{|c|c|}
\hline Nasrani & $\begin{array}{l}\text { : Ayo su e, mari makan su } \\
\text { (Ayo mari makan dulu) }\end{array}$ \\
\hline Muslimin & $\begin{array}{l}\text { : Adu mati su, beta lupa bawa dompet } \\
\text { (Adu gawat, saya lupa bawa dompet) }\end{array}$ \\
\hline Nasrani & $\begin{array}{l}\text { Ko lupa di mana? } \\
\text { (Memangnya lupa di mana?) }\end{array}$ \\
\hline Muslimin & $\begin{array}{l}\text { : Lupa di rumah to, ini ko be bale dolo } \\
\text { (Lupa di rumah, saya pulang ambil dulu) }\end{array}$ \\
\hline Nasrani & $\begin{array}{l}\text { : Na makan dolo baru bale to } \\
\text { (Kalau begitu makan dulu baru pulang) }\end{array}$ \\
\hline Muslimin & $\begin{array}{l}\text { : Sonde, beta pi ambe cepat-cepat } \\
\text { (Tidak, saya pergi ambil cepat-cepat) }\end{array}$ \\
\hline
\end{tabular}

Kutipan di atas menunjukan bahwa penutur muslim meolak tawaran dari mitra tuturnya dengan cara mengalihkan topik pembicaraan. Awalnya penutur nasrani menawarkan makan kepada penutur penutur muslim, namun penutur muslim sontak terkaget dan berujar kalau ia lupa membawa dompetnya (adu mati su, beta lupa bawa dompet) yang tertinggal di rumah (lupa di rumah to, ini ko be bale dolo). Kaget merupakan cara yang digunakan penutur muslim untuk mengalihkan pembicaraan, sehingga mitra tuturnya lebih terfokus pada hal yang dialami oleh penutur muslim. Walau penutur nasrani sempat mengembalikan topik pembicaraan ke tawaran makan, manun penutur muslim menghindarinya dengan berpamitan untuk mengambil dompetnya yang tertinggal di rumahnya (sonde, beta pi ambe cepat-cepat).

\section{KESIMPULAN}

Berdasarkan pembahasan di atas, dapat disimpulkan bahwa terdapat sembilan bentuk bahasa penolakan dari masyarakat muslim terhadap tawaran atau ajakan makan dari masyarakat nasrani di Kota Kupang. Kesembilan bentuk bahasa penolakan tersebut dapat diklasifikan menjadi bentuk bahasa penolakan langsung dan bentuk bahasa penolakan tidak langsung. Bentuk bahasa penolakan langsung terdiri dari dua kategori yaitu penolakan performatif dan penolakan konstantif. Sedangkan bentuk bahasa penolakan tidak langsung terdiri dari tujuh ketegori yaitu penolakan dengan alasan, penolakan dengan alternatif, penolakan dengan berjanji, penolakan dengan penyesalan, penolakan dengan penerimaan di masa depan, penolakan dengan prinsip, dan penolakan dengan penghindaran. Kesemua bentuk bahasa penolakan tersebut pada dasarnya tidak bermaksud untuk tidak menghargai tawaran atau ajakan makan dari kaum nasrani, tetapi bertujuan untuk menjaga nilai-nilai ajaran yang terkandung di dalam agama Islam yang harus diamalkan oleh setiap muslim. Hal tersebut dapat dilihat dari tidak adanya kata-kata yang terkesan negatif seperti hinaan, sindiran, dan lain sebagainya dalam bahasa penolakan tersebut. 


\section{DAFTAR PUSAKA}

Hermaji, Bowo. 2013. Tindak Tutur Penerimaan dan Penolakan dalam Babasa Indonesia. Cakrawala, 7 (01), 1 - 10

Kridalaksana, Harimurti. 1983. Kamus Linguistik. Jakarta: PT. Gramdia 2008. Kamus Linguistik. Jakarta: PT. Gramdia

Kartomihardjo. 1990. Bahasa Cermin Kehidupan Masyarakat. Jakarta: Depdikbud

Leech, Geoffrey. 1993. Prinsip-prinsip Pragmatik. Diterjemabkan oleh M. D. D. Oka; pendamping Setyadi Setyapratama. Jakarta: Universitas Indonesia (UI-Press)

Mada, Bayu Kusuma. 2013. Analisis Ungkapan Penolakan Babasa Jepang dalam Film Ranma 1/2.Skirpsi.Semarang: Universitas Dian Nuswantoro.

Maknunah Durrotul. 2014. Ungkapan Penolakan dalam Serial Drama "Itazura Na Kiss Love In Tokyo" Karya Tada Karou. Mahasiswa FIB. 5 (09)

Muzakkar, Sultar, dan Andi Agussalim AJ. 2020. Analisis Bahasa Penolakan dalam Diskusi Kelas. Pembelajaran Bahasa dan Sastra Indonesia, 1 (01), 18 - 24

Permata, Astiria. 2016. Analisis Penggunaan Strategi Penolakan Tidak Langsung dalam Bahasa Jepang. Sora, 1 (01), $9-17$

Putri, Ni Made Mia Septiarini, Ngurah Indra Pradhana, I Nyoman Rauh Artana. 2020. Ujaran Penolakan dalam Bahasa Jepan dan Bahasa Bali. Sakura. 2 (01), 49 - 62

Utami, Tri Budi. 2006. Analisis Pragmatik Bahasa Penolakan dalam Wacana Chatting di Internet Netzone. Skripsi. Surakarta: Universitas Muhammadiyah Surakarta.

Yamagashira, Hisako. 2001. Pragmatic Transfer in Japanese ESL Refuals. Junshinjonsi: Kagoshima 